\title{
BIODIVERSITY LOSS AND ITS SOLUTIONS
}

Ha Thi Hong Hanh, Ha Minh Hang, Duong Minh Hang, Nguyen Thi Thu Ha, Nguyen Thi Hang, Nguyen Khanh Toan, Chu Nguyet Ha, Hoang Truong Giang, Tran Thi Linh Dan, Nguyen Linh Giang, Nguyen Mai Ha

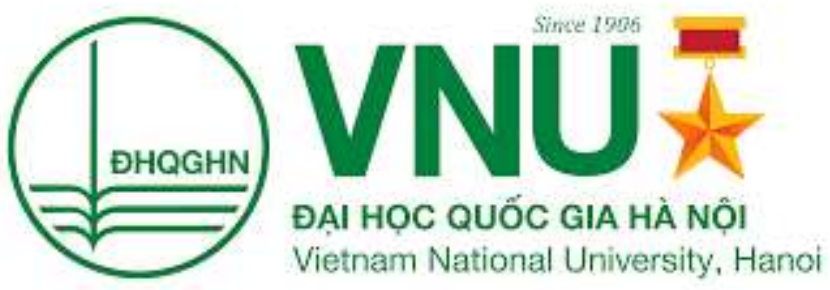

Vietnam National University, Hanoi

January 15 th 2022

Preprint DOI: https://osf.io/ydu95/

Protecting biodiversity is an important prerequisite for global development and the provision of goods, the foundation of the food supply, and an important foundation of health. It has an important place in human nutrition through its role in global food production; ensure land productivity and provide genetic resources for plants (Julie Shaw, 2021). In the past decades, besides the strong cultural and economic development, the loss of biodiversity has also occurred at a rapid rate in the world that every country has to face. Currently, there are more than 1 million plant and animal species on about eight million species on Earth that are at an endangered level. 


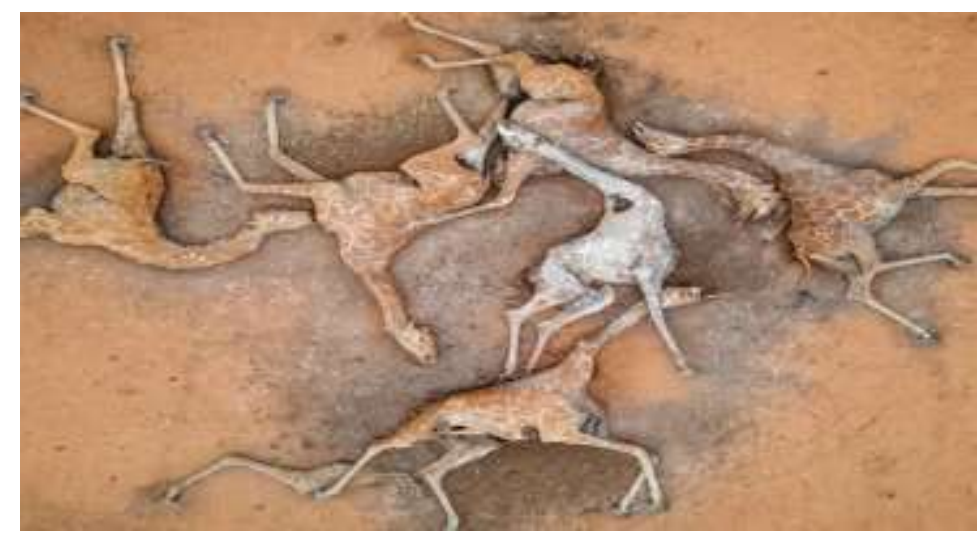

Figure 1: Six giraffes died in drought in Kenya

\section{Credit: Oliver Holmes}

In Vietnam, as can be seen from the data analysis, $21 \%$ of mammal species, $6.5 \%$ of birds, $19 \%$ of reptiles, $24 \%$ of amphibians, $38 \%$ of fish species and $2.5 \%$ of plant species the object is in serious danger (Nicolas Loiseau, 2020). It can be said that the biodiversity of Vietnam today is deeply influenced by the history of war and the culture that relies on natural resources. During wartime, at least 2.2 million hectares of forest were affected between 1943-1973. After the war, due to the need for economic development, forest resources continuously decreased.

In addition, using wild animals to serve the living needs of forest-based communities has put many animal species at risk of extinction, such as primates. Besides, there are many other causes such as invasive alien species, environmental pollution (fossils: oil, gas, coal...), over-exploitation of natural resources, land conversion without sufficient scientific evidence, infrastructure development, development Agriculture meets the rapid population growth, reduces forest area and environmental pollution (Forest Isbell, 2010).

\section{Nguyên nhân làm giảm đa dạng sinh học}

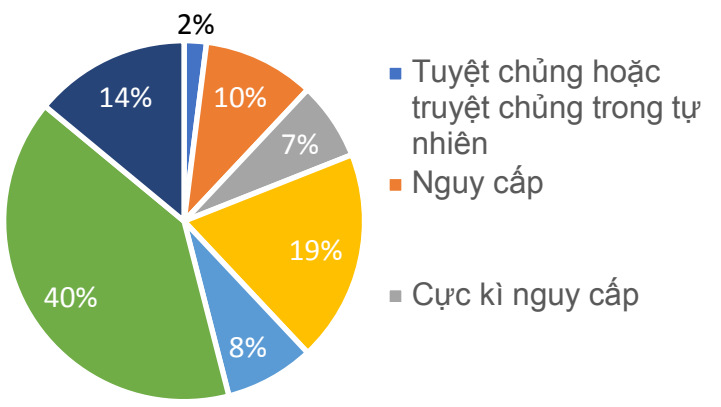

Figure 2: Causes of biodiversity loss 
Credit: Department of Nature Conservation and Biodiversity, Vietnam Environment Administration

(https://domainofscience.wordpress.com/2016/05/22/international-biodiversity-

day/?fbclid=IwAR258mRa8eUp9sRZ8TgEtzU9yIbaZNca6qMUfERfU26piEuTrB-HOvthV34)

Since then, the reduction of diversity in animals and plants causes serious dangers such as ecological imbalance, directly affecting the living environment of humans, threatening the sustainable development of the earth, affecting the sustainable development of the earth. affecting food security exposes people to risks and poverty [8]. Therefore, we need to raise awareness and change human behavior towards biodiversity conservation (Q. Vuong, 2020).

Over the past century, the world has realized efforts by establishing non-profit organizations, opening many conferences, signing conventions for the conservation of flora and fauna: Fauna World Organization for the Conservation of Fauna and Flora. \& Flora International (Andy Coghlan, 2016), Animals Asia Foundation (hongkongvolunteer, 2017), Wildlife Conservation Society (WCS) (Thang Nguyen, 2021), Animal Defenders International ( ADI) (ADI, 2021), International Day of Biological Diversity on 22 May every year (Phuong Dung, 2020), CITES Convention (Dinh Thuy Dung, 2021),....

From 11 to 15 October 2021, the 15th Meeting of the Parties to the Convention on Biological Diversity, or COP15, called on the world to agree on averting crises; "urgent and coordinated" action by all parties. Furthermore, to mitigate the increasingly serious loss of biodiversity, countries are committed to ensuring active and effective participation in the "Global Biodiversity Framework beyond 2020". As the host country, China has taken the lead in launching a bioprotection fund for developing countries and announced a contribution of 1.5 billion yuan to the fund (United Nations System Chief Executives Board For Coordination, 2021).

Although the world has been trying to implement remedial measures to reduce diversity in animals and plants, there are policies that have not achieved the desired effectAmong them, the "United Nations Decade on Biodiversity" for the period 2011-2020, has not achieved the ambition of biodiversity set forth in the 2030 sustainable development agenda and does not protect ecosystem that plays a vital role for humans [9]. In 2010, 196 countries that are party to the United Nations Convention on Biological Diversity agreed to 20 plant conservation goals called the AICHI biodiversity goals. However, most of them did not achieve the expected goals, only 6 goals achieved partial results and some targets even went in the wrong direction (Sandra Díaz, Josef Settele, Eduardo Brondízio, Hien T. Ngo, Maximilien Guèze; John Agard, Almut Arneth, Patricia Balvanera, C. Z., 2019). 
For the purpose of preserving biological populations, rare species of flora and fauna, the primitive ecological environment, biological relics of historical significance and value for scientific research and biological populations that bring great environmental benefits for scientific research and scientific education, Vietnam built 168 protected areas eco included 33 national parks, 59 natural reserves, 13 species conservation areas, 9 biosphere reserves, 54 landscape protection areas,...

In addition, from 2016 to 2021, Vietnam and the United States Agency for International Development (USAID) cooperated to protect biodiversity to reduce illegal wildlife consumption, strengthen law enforcement, improve prosecutions, coordinate regulatory frameworks, and reduce the need for illegal wildlife poaching and wildlife products called "Project to prevent illegal trade in wild animals and plants". The project has also provided professional support to more than 2,600 officers from forest rangers, customs, environmental police, fresh market managers, border guards, courts and inspectors to master the skills. skills and knowledge related to wildlife crime. Compared to the early project data, the rate of prosecution, trial / arrest for wildlife protection violations increased from 25\% in 2018 to $75 \%$ in August 2021.

In short, under the pressure of development and the impact of the global environment, the risk of loss and degradation of flora and fauna has caused serious consequences for the sustainable development of the country. In the current context, strengthening conservation of flora and fauna is an urgent issue of countries. In light of the 3DMS and environmental culture tower (Khuc, 2021), we could have more chance to find the innovative solutions to the problem aforementioned (Vuong, Q. H., 2022; Q. H. Vuong, 2021). As such, more financial investment in research (Q. H. Vuong, 2018), communications and collaborations are required to help protect and nurture nature. We need more strong action, timely solutions, and thorough efforts in the protection and good management of the ecosystem (Q.-H. Vuong, 2021).

\section{References:}

ADI. (2021). TEAPSPA Launch: Launch of bill to stop circus suffering in the United States Animal Defenders International. ADI. https://www.ad-international.org/adi_home/

Andy Coghlan. (2016). Biodiversity betrayed as nations fail miserably on conservation. Magazine Issue 3103. https://www.newscientist.com/article/2115585-biodiversity-betrayal-as-nations-fail-miserablyon-conservation/

Dinh Thuy Dung. (2021). Công ước quốc tế về buôn bán các loại động, thực vật hoang dã nguy cấp. Luật 
Dưong Gia. https://luatduonggia.vn/cong-uoc-quoc-te-ve-buon-ban-cac-loai-dong-thuc-vat-hoang-danguy-cap/

Forest Isbell. (2010). Causes and consequences of biodiversity declines. Nature Education Knowledge. https://www.nature.com/scitable/knowledge/library/causes-and-consequences-of-biodiversitydeclines-16132475/

hongkongvolunteer. (2017). Volunteer for Animals Asia Foundation. Volunteering in Hong Kong. https://hongkongvolunteer.wordpress.com/2017/07/24/volunteer-animals-asia/

Julie Shaw. (2021). Why is biodiversity important? Conservation International. https://www.conservation.org/blog/why-is-biodiversity-important

Khuc, Q. Van. (2021). Environmental culture thoughts to make a better world for our nature and children. OSF Preprints. https://doi.org/10.31219/osf.io/g5zex

Nicolas Loiseau, N. M. (2020). Global distribution and conservation status of ecologically rare mammal and bird species. Nat Commun 11, 5071. https://www.nature.com/articles/s41467-020-18779-w

Phuong Dung. (2020). Hưởng ứng Ngày quốc tế Đa dạng sinh học 2020. Cổng Thông Tin Điện Tử Huyền AE H’LEO. https://eahleo.daklak.gov.vn/huong-ung-ngay-quoc-te-a-dang-sinh-hoc-2020-931.html

Sandra Díaz, Josef Settele, Eduardo Brondízio, Hien T. Ngo, Maximilien Guèze; John Agard, Almut Arneth, Patricia Balvanera. (2019). Báo cáo đánh giá toàn cầu về đa dạng sinh học và các dịch vụ hệ sinh thái - tóm tắt dành cho các nhà hoạch định chính sách. In Tổ chức Bảo tồn Thiên nhiên Quốc tế (IUCN) và Cục Bảo tồn thiên nhiên và Đa dạng Sinh học, Tổng cuc Môi trương, Bộ Tài nguyên \& Môi trường Việt Nam với sụ hố trọ̣ tài chính của Cục môi truờng Na Uy (NEA). https://ipbes.net/sites/default/files/202104/ipbes_global_assessment_report_summary_for_policymakers_vi.pdf.pdf?fbclid=IwAR2oY08TK UXE27bpQpF0PDXV1FaQcfxpUrj7WeHENGLyfE_5peS_6t5mleI

Thang Nguyen. (2021). Góc nhìn báo chí | Buôn bán trái pháp luật động vật hoang dã tại Việt Nam | Quý III. WCS Vietnam. https://programs.wcs.org/vietnam/vi-vn/News/Wildlife-Trade-NewsVN/ID/16870/Goc-nhin-bao-chi-Buon-ban-trai-phap-luat-ong-vat-hoang-da-tai-Viet-Nam-Quy-III2021.aspx

United Nations System Chief Executives Board For Coordination. (2021). UN System Statement of Purpose : COP 15. CEB. https://unsceb.org/un-system-statement-purpose-cop15 
Vuong, Q. H., et al. (2022). Covid-19 vaccines production and societal immunization under the serendipity-mindsponge-3D knowledge management theory and conceptual framework. Humanities and Social Sciences Communications, 9; doi:10.1057/s41599-022-01034-6. Available at: https://www.nature.com/articles/s41599-022-01034-6

Vuong, Q.-H. (2021). Western monopoly of climate science is creating an eco-deficit culture. Economy, Land \& Climate Insight, 11, 1-9. https://elc-insight.org/western-monopoly-of-climat

Vuong, Q. (2020). From children's literature to sustainability science, and young scientists for a more sustainable Earth From children's literature to sustainability science, and young scientists for a more sustainable Earth. Journal of Sustainability Education, 24(December), 2019-2021.

Vuong, Q. H. (2018). The (ir)rational consideration of the cost of science in transition economies. Nature Human Behaviour, 2(1), 5. https://doi.org/10.1038/s41562-017-0281-4

Vuong, Q. H. (2021). The semiconducting principle of monetary and environmental values exchange. Economics and Business Letters, 10(3), 284-290. https://doi.org/10.17811/ebl.10.3.2021.284-290 
